\title{
Revisiting the Exports and Economic Growth Nexus: Rolling Window Cointegration and Causality Evidence from Cote d'Ivoire, Malaysia, Pakistan and South Africa
}

\author{
Yaya Keho' \\ 'National School of Statistics and Applied Economics (ENSEA) Abidjan, Côte d'Ivoire \\ Email:yayakeho@yahoo.fr
}

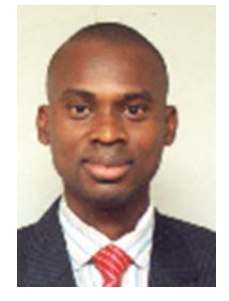

\begin{abstract}
This paper reexamines the relationship between exports and economic growth in Cote d'Ivoire, Malaysia, Pakistan and South Africa using time-varying cointegration and causality tests. The cointegration results suggest that exports, investment in physical capital and GDP move together in the long-run in the four countries. Furthermore, the full sample Granger causality tests support the export-led growth hypothesis for Malaysia and Pakistan, and the growth-led exports hypothesis for South Africa. However, the rolling window cointegration and causality tests show that the long-run and also the causal relationships between exports and GDP are time-varying. For most time periods we do not find any causal relationship between exports and GDP. There are, however, sub-periods during which unidirectional or bidirectional causal relations were found. Therefore, export-promoting strategies are not always effective tools to stimulate economic growth.
\end{abstract}

Keywords: Exports, Economic growth, Rolling window regression, Causality, Cointegration, Export-led growth, Growth-led exports. JEL Classification: C32, F10, F43, O57.

Citation | Yaya Keho (2019). Revisiting the Exports and Economic Growth Nexus: Rolling Window Cointegration and Causality Evidence from Cote d'Ivoire, Malaysia, Pakistan and South Africa. Asian Journal of Economics and Empirical Research, 6(1): 27-35. History:

Received: 24 October 2018

Revised: 19 November 2018

Accepted: 1 January 2019

Published: 21 January 2019

Licensed: This work is licensed under a Creative Commons

Attribution 3.0 License $(\text { (c) })_{\text {Er }}$

Publisher: Asian Online Journal Publishing Group
Funding: This study received no specific financial support.

Competing Interests: The author declares that there are no conflicts of interests regarding the publication of this paper.

Transparency: The author confirms that the manuscript is an honest, accurate, and transparent account of the study was reported; that no vital features of the study have been omitted; and that any discrepancies from the study as planned have been explained.

Ethical: This study follows all ethical practices during writing.

\section{Contents}

1. Introduction

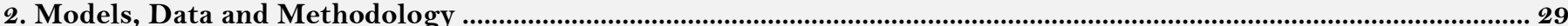

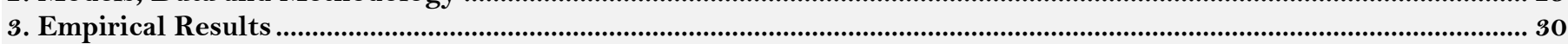

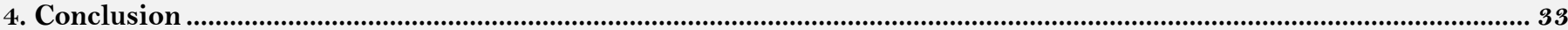

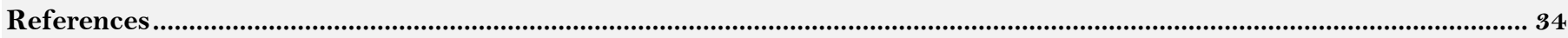




\section{Introduction}

Over the past decades, the relationship between exports and economic growth has been the subject of a growing literature. This attention increased when East Asian economies that have relied on exports have achieved spectacular success in accelerating their economic growth. It is in view of this success that developing countries pursue export-promotion policies in order to boost economic growth. However, the empirical evidence regarding the causal relationship between exports and economic growth is inconclusive. A number of studies found that exports lead to economic growth (Mamun and Nath, 2005; Jordaan and Eita, 2007; Hamdi, 2013; Arodoye and Iyoha, 2014) while others found that economic growth drives exports (Ahmad and Kwan, 1991; Dhawan and Biswal, 1999; Chandra and Love, 2005; Srivastava and Kapoor, 2007; Alimi and Muse, 2013; Hassan and Murtala, 2016). Further studies still reported a bidirectional causal relationship between exports and economic growth (Chandra, 2003; Mahadevan, 2007; Tsen, 2010; Alimi, 2012; Jarra, 2013; Kumari and Malhotra, 2014; Lam, 2016) while others failed to find any significant causal relationship between the two variables (Tang, 2006; BahmaniOskooee and Economidou, 2009).

A number of shortcomings explain these contradictory findings. First, most of previous studies have relied on a bivariate framework in which the role of other relevant variables such as capital has been ignored. It is well-known that causality tests are sensitive to omitted variables (Lütkepohl, 1982) and hence bivariate models may not be suitable for testing the export-growth nexus. Second, causality testing in these studies is based on autoregressive models in which the choice of the order for lags is crucial. Third, as they employed short data spans, most previous works may suffer from the "small sample" problem, which may lead to misleading inferences (Dolado and Lütkepohl, 1996; Hatemi-j, 2002). Finally, these studies used linear time series approaches in which parameters are assumed to be constant over time. They do not account for structural changes and nonlinearities in the causal relationship between exports and economic growth. The causal nexus between exports and economic growth variables may be unstable owing to frequent changes in the global economic and political environments. Ignoring these changes may result in misleading results.

This study addresses these shortcomings by using bootstrap and rolling regression methods to reexamine the exports and economic growth nexus for Cote d'Ivoire, Pakistan, Malaysia and South Africa. These countries have been examined previously, yielding to contradictory results. In the case of Cote d'Ivoire, Abdulai and Jacquet (2002) found evidence supporting the export-led growth hypothesis over the period 1961 to 1997. For South Africa, Ukpolo (1998) failed to validate the export-led growth hypothesis but provided support for the growth-led export hypothesis. On the contrary, Rangasamy (2009) provided support for the export-led growth hypothesis for South Africa. Reppas and Christopoulos (2005) also found evidence supporting the growth-led export and not the export-led growth hypothesis for Cote d'Ivoire, Gabon, South Africa, Malaysia, and Pakistan. In the case of Pakistan, Love and Chandra (2004); Shirazi and Manap (2005); Parida and Sahoo (2007) and Shahbaz et al. (2011) confirmed the export-led growth hypothesis, while Bahmani-Oskooee (1993); Khan and Saqib (1993) and Saleem and Sial (2015) found bidirectional causal relationship between exports and output, and Dodaro (1993), Afzal and Hussain (2010) and Kumari and Malhotra (2015) found no causal relationship between exports and economic growth. For Malaysia, Islam (1998) did not find any causal relationship between exports and economic growth, while Al-Yousif (1999); Ekanayake (1999) and Choong et al. (2005) provided evidence confirming the export-led growth hypothesis, and Hassan and Murtala (2016) found evidence validating the growth-led export hypothesis. Furthermore, Baharumshah and Rashid (1999); Furuoka (2007); Mahadevan (2007) and Lam (2016) found evidence of bidirectional causal link between the two variables.

This study uses the rolling window regression to reconsider these conflicting findings. The study aims at showing that instability of the causal relationships between exports and economic growth is one of the reasons explaining the contradictory findings in the empirical literature. We use a time-varying approach to analyze the relationship between exports and economic growth for at least two reasons. First of all, the economic environment is subject to instabilities, which cause the coefficients to change over time. Instability may occur due to economic crisis, oil price shocks, financial crisis, shifts in monetary policy, technological changes and political instability. It is well known by now that these shocks lower the power of standard tests of stationarity, cointegration and causality. Another reason is given by the famous Lucas critique that is coefficients change if an anticipated change in the policy regime occurs. Furthermore, the sample periods of our study cover a number of events that may have significant impact upon the export-growth nexus. In particular, over the periods, a number of developing countries shifted their strategy from import-substitution to export promotion. In a study of Malaysia, Khalafalla and Webb (2001) confirmed the export-led growth for the period 1965-1980 when policy was on import-substitution, and the growth-led exports for the export promotion period (1981-1996). Stability is a desirable condition to formulate and implement effective macroeconomic policy. However, stability of the causal relationship between exports and economic growth has not been extensively investigated. Time-varying regression methodology is an appealing approach given its ability to show the periods in which exports have causal effect on economic growth. Tang (2013) was the first study using the rolling regression-based causality tests to investigate the export-growth nexus for Malaysia over the period 1975-2010. The full sample results indicated a bidirectional causal relationship between exports and output. However the rolling window causality results show that the causal relationship is unstable over time. Subsequently, Tang et al. (2015) examined the export-growth relationship for Hong Kong, South Korea, Singapore and Taiwan. When the full sample is used, they found evidence of bidirectional causality between exports and GDP. Furthermore, using rolling causality tests they found that this causal relation is unstable over time. Yang and Wu (2015) revisited the causal nexus between exports and GDP for China and Taiwan using rolling window Granger causality tests. The results from full sample tests show evidence of bidirectional causality between the two variables. However, the results from rolling regressions indicate that the export-led growth hypothesis holds in some periods for China but not for Taiwan. On the contrary, the growth-led export model is supported in some periods for both China and Taiwan. However, their study does not apply rolling regression to cointegration tests. In this study, we incorporate rolling regression technique into the bounds test to cointegration suggested by Pesaran et al. (2001) and the Granger causality test developed by Toda and Yamamoto (1995). 
The remainder of the paper is organized as follows. Section 2 outlines the methodology of the empirical analysis. Section 3 presents the empirical results, and Section 4 concludes the study.

\section{Models, Data and Methodology}

\subsection{Model and Data}

The econometric model that will be used in this study is specified as follows:

$$
y_{t}=\theta_{0}+\theta_{1} x_{t}+\theta_{2} k_{t}+\mu_{t}
$$

where $y, k$, and $x$ represent the log of real GDP, real capital, and real exports, respectively.

The study uses annual data for Cote d'Ivoire, Malaysia, Pakistan and South Africa. The data set for each country consists of observations for real GDP (GDP), real exports (Exports) and real gross fixed capital formation as proxy for capital (Capital). The data is sourced from the World Development Indicators of the World Bank. Real GDP, real exports and real gross fixed capital formation are in constant 2005 US dollar. Real exports have been computed on the basis of their shares in GDP. The study period differs across countries, depending on data availability. Data for Cote d'Ivoire cover the period 1965-2014; data for Malaysia and South Africa cover the period 1960-2014; and data for Pakistan are for the period 1967-2014. All the series are converted into natural logarithms.

\begin{tabular}{|c|c|c|c|c|c|c|c|c|}
\hline \multirow[b]{2}{*}{ Country } & \multirow[b]{2}{*}{ Sample } & \multicolumn{2}{|l|}{ GDP } & \multicolumn{2}{|c|}{ Capital } & \multicolumn{2}{|c|}{ Exports } & \multirow[t]{2}{*}{$\rho$} \\
\hline & & Mean & Sd. & Mean & Sd. & Mean & $\mathrm{Sd}$. & \\
\hline Cote d'Ivoire & $1965-14$ & 23.29 & 0.37 & 21.34 & 0.36 & 22.37 & 0.46 & 0.95 \\
\hline Malaysia & $1960-14$ & 24.56 & 1.01 & 23.04 & 1.26 & 24.17 & 1.32 & 0.99 \\
\hline Pakistan & $1967-14$ & 24.70 & 0.68 & 23.21 & 0.51 & 22.65 & 0.84 & 0.97 \\
\hline South Africa & $1960-14$ & $\begin{array}{ll}2 & .81\end{array}$ & 0.44 & 23.98 & 0.52 & 24.51 & 0.47 & 0.96 \\
\hline
\end{tabular}

Table 1 reports some descriptive statistics on the variables. The correlation coefficient suggests a positive relationship between exports and GDP. However, correlation does not mean causality. Is there any evidence of the export-led growth or the reverse? Does any causality exist between exports and GDP in the countries under study? Our empirical analysis will address these questions.

\subsection{The Bounds Testing Approach to Cointegration}

The study uses the bounds testing approach to cointegration to investigate the long-run relationship between exports and economic growth within the autoregressive distributed lag (ARDL) model. The choice of this method lies in its small sample properties that have been documented in the literature (Cheung and Lai, 1993; Inder, 1993; Pesaran et al., 2001). The bounds testing procedure is based on the following equation:

$\Delta y_{t}=\phi_{0}+\phi_{1} y_{t-1}+\phi_{2} x_{t-1}+\phi_{3} k_{t-1}+\sum_{i=1}^{m} \gamma_{1 i} \Delta y_{t-i}+\sum_{i=0}^{n} \gamma_{2 i} \Delta x_{t-i}+\sum_{i=0}^{p} \gamma_{3 i} \Delta k_{t-i}+e_{t}$

where $\Delta$ is the difference operator, $\phi_{1}, \phi_{2}$ and $\phi_{3}$ the long-run multipliers and $\phi_{0}$ is the drift constant, while $\gamma_{1 \mathrm{i}}, \gamma_{2 \mathrm{i}}$ and $\gamma_{3 \mathrm{i}}$ are the short-run dynamics of the variables. It should be noted that Eq. (2) is estimated using each variable as the dependent variable.

The presence of long-run relationship is tested by restricting coefficients of lagged level variables equal to zero. That is, the null hypothesis of no long-run relationship is $\phi_{1}=\phi_{2}=\phi_{3}=0$. This hypothesis is tested by the mean of an $F$-test. The asymptotic critical values are provided by Pesaran et al. (2001). The bounds testing procedure is sensitive to the selection of the lag structure $(m, n, p)$. In this study, maximum lag length on each variable was set to five.

\subsection{Toda-Yamamoto Granger Causality Test}

To test for Granger causality between exports and GDP, this study employs the modified-Wald test proposed by Toda and Yamamoto (1995). This approach has the advantage of not requiring pre-testing for cointegration among the variables. It makes inference valid even when the variables are mixed integrated or cointegrated. The basic idea of this approach is to artificially augment the correct VAR order, $p$, with $d$ extra lags, where $d$ is the maximum likely order of integration of the series. Thus, the model VAR to be estimated is as follows:

$$
\left[\begin{array}{l}
y_{t} \\
x_{t} \\
k_{t}
\end{array}\right]=\left[\begin{array}{l}
\alpha_{1} \\
\alpha_{2} \\
\alpha_{3}
\end{array}\right]+\sum_{i=1}^{p}\left[\begin{array}{lll}
\beta_{1 i} & \gamma_{1 i} & \delta_{1 i} \\
\beta_{2 i} & \gamma_{2 i} & \delta_{2 i} \\
\beta_{3 i} & \gamma_{3 i} & \delta_{3 i}
\end{array}\right] \times\left[\begin{array}{c}
y_{t-i} \\
x_{t-i} \\
k_{t-i}
\end{array}\right]+\sum_{i=p+1}^{p+d}\left[\begin{array}{ccc}
\beta_{1 i} & \gamma_{1 i} & \delta_{1 i} \\
\beta_{2 i} & \gamma_{2 i} & \delta_{2 i} \\
\beta_{3 i} & \gamma_{3 i} & \delta_{3 i}
\end{array}\right] \times\left[\begin{array}{c}
y_{t-i} \\
x_{t-i} \\
k_{t-i}
\end{array}\right]+\left[\begin{array}{c}
e_{1 t} \\
e_{2 t} \\
e_{3 t}
\end{array}\right]
$$

Once this augmented level VAR is estimated, a standard Wald test is applied to the first lagged $p$ explanatory variables to make causal inference. For example, the null hypothesis that exports do not Granger cause GDP is $\gamma_{11}=\gamma_{12}=\ldots=\gamma_{1 \mathrm{p}}=0$. Similarly, the null hypothesis that GDP does not Granger cause exports is $\beta_{21}=\beta_{22}=\ldots=\beta_{2 \mathrm{p}}$ $=0$. The computed Wald-statistic has an asymptotic chi-square distribution with the degree of freedom equal to the number of constraints.

\subsection{Rolling Window Regression Technique}

The full-sample cointegration and Granger causality tests assume that the parameters of the models are constant over the entire sample period. This assumption is often violated because of frequent changes in the 
economic environment. In order to overcome the time-varying relationship between exports and GDP, we incorporate the rolling regression technique into the bounds test and the Granger causality test.

The rolling window regression is based on changing subsamples of fixed size that sequentially roll over the sample period by adding one observation at the end of the sample while dropping one at the beginning. With window size $l$ and full series length $T$, this method provides a sequence of $T$ - $l$ regressions. In this study, we choose a rolling window size of 25 years. Thus, the first test statistic was estimated by using a subsample period from 1960 to 1989 for Malaysia and South Africa. The second test statistic was estimated by using data from 1961 to 1990. This rolling regression procedure continues until the last observation enters the regression. For interpretation, the 25-years rolling F-statistics for bounds tests are normalized by their 10 percent upper critical values computed using the simulation procedure described in Pesaran et al. (2001). For values of the normalized Fstatistic higher than 1.00, the null hypothesis of no long-run relationship is rejected.

The rolling window procedure is also applied to the Toda-Yamamoto Granger causality test. That is, we estimate an augmented level VAR model for a time span of 25 years rolling over the whole sample period. We then calculate the p-values of the rolling Wald statistics for the null hypothesis of Granger non-causality using residualbased bootstrap method. The principle of the residual-based bootstrap method involves drawing a number of mean adjusted residuals with replacement from the restricted model under the null hypothesis, then generating the dependent variable and calculating the test statistic. Repeating this process 1000 times, we obtain the bootstrap $p$ value as the percentage of bootstrap test statistics exceeding the observed test statistic. If the bootstrap $p$-value is lower than 0.10 then the null hypothesis is rejected. In other words, if the export-led growth hypothesis holds, then a large number of $p$-values will be lower than 0.10 when the sample rolls forward.

\section{Empirical Results}

\subsection{Unit Root and Cointegration Test}

Prior to investigating cointegration and causality, we conduct unit root tests to determine the order of integration for each series. This step is necessary to ensure that no variable is integrated at order two. We apply the unit root test of Phillips and Perron (1988). This test has been performed under the models with constant and trend. The results displayed in Table 2 suggest that all the variables are integrated of order one. Based on these results, the next step is to test for cointegration.

\begin{tabular}{|c|c|c|c|c|c|c|}
\hline \multirow[b]{2}{*}{ Country } & \multicolumn{3}{|l|}{ Level } & \multicolumn{3}{|c|}{ First difference } \\
\hline & GDP & $\mathbf{X}$ & $\mathbf{K}$ & $\Delta G D P$ & $\Delta \mathbf{X}$ & $\Delta \mathbf{K}$ \\
\hline Cote d'Ivoire & $-3.209^{\text {*** }}$ & -2.746 & -1.963 & $-4.267^{*}$ & $-7.467^{*}$ & $-5.434^{*}$ \\
\hline Malaysia & -1.154 & -1.267 & -1.911 & $-6.476^{*}$ & $-5.645^{*}$ & $-5.194^{*}$ \\
\hline Pakistan & -0.909 & -1.192 & -1.335 & $-5.822^{*}$ & $-8.960^{*}$ & $-5.658^{*}$ \\
\hline South Africa & -2.944 & -2.205 & -1.474 & $-4.484^{*}$ & $-5.902^{*}$ & $-3.702^{*}$ \\
\hline
\end{tabular}

Note: GDP, K and X denote log of real GDP, real capital and real exports, respectively. * and ${ }^{* *}$ denote the rejection of the null hypothesis of unit root at the $5 \%$ and $10 \%$ levels, respectively.

The results of the bounds test disclosed in Table 3 support the presence of a long-run relationship between exports, gross fixed capital formation and GDP for the four countries under study. The estimates of the long-run coefficients indicate that exports and GDP are positively correlated in the long-run. Furthermore, the results support the export-led growth for Cote d'Ivoire and Malaysia. Exports are playing a significant role in the economic growth of these two countries. On the contrary, the results for South Africa support the growth-driven exports hypothesis.

Table-3. Results of bounds test for cointegration

\begin{tabular}{|c|c|c|c|c|c|}
\hline & \multirow[t]{2}{*}{$\mathbf{F}_{\mathrm{GDP}}$} & \multirow[t]{2}{*}{$\overline{F_{x}}$} & \multirow[t]{2}{*}{$\overline{F_{K}}$} & \multicolumn{2}{|c|}{$10 \%$ Critical bounds } \\
\hline & & & & $\mathrm{I}(\mathbf{0})$ & $\mathrm{I}(1)$ \\
\hline Cote d'Ivoire & $7.900^{*}$ & 3.161 & 3.750 & 4.188 & 4.979 \\
\hline Malaysia & $5.072^{*}$ & 3.530 & $5.343^{*}$ & 4.225 & 4.702 \\
\hline Pakistan & 2.969 & 4.123 & $12.527^{*}$ & 4.188 & 4.979 \\
\hline South Africa & $8.877^{*}$ & $8.815^{*}$ & 1.907 & 4.225 & 4.702 \\
\hline
\end{tabular}
computed from simulations as described by Pesaran et al. (2001). Maximum lag length on each variable was set to 5 .

Table-4. Lon-run estimates

\begin{tabular}{l|l|l|l|l}
\hline \multirow{2}{*}{ Country } & \multicolumn{3}{|l|}{ Dependent variable is GDP } & Dependent variable is Exports \\
\cline { 2 - 5 } & Coef. & t-stat. & Coef. & t-stat. \\
\hline Cote d'Ivoire & $0.344^{* *}$ & 1.956 & $0.422^{* *}$ & 1.740 \\
\hline Malaysia & $0.119^{*}$ & 6.644 & $5.762^{*}$ & 7.075 \\
\hline Pakistan & $0.089^{*}$ & 3.543 & $3.671^{*}$ & 3.613 \\
\hline South Africa & 0.010 & 0.122 & $0.555^{*}$ & 2.772 \\
\hline Note: * and **indicate significance at the 5\% and 10\% levels, respectively.
\end{tabular}

Note: " and **indicate significance at the $5 \%$ and $10 \%$ levels, respectively.

\subsection{Full-Sample Ganger Causality Test Results}

Before testing for causality, it is necessary to determine the lag length of the VAR models. The optimal lag length of each VAR model is determined using four criterions: Akaike Information Criterion (AIC), Schwarz Information Criterion (SC), Hannan-Quinn Information Criterion (HQ), and Final Prediction Error (FPE). As the maximal integrated order of the series is 1 , we estimate level VARs of order $p=k+1$ in the Toda-Yamamoto procedure. The results of the full sample Granger causality test are presented in Table 5 . These results indicate that exports have predictive power for economic growth in Malaysia and Pakistan, while economic growth has 
predictive power for exports in South Africa. There is no causal relationship between exports and GDP for Cote d'Ivoire. In other words, these results suggest that within the entire sample period (1960/67-2014) the export-led growth hypothesis holds for Malaysia and Pakistan, while the growth-led exports hypothesis is vindicated in South Africa, and there is no support for neither of the two hypotheses for Cote d'Ivoire. These findings are in line with the results by Ukpolo (1998) for South Africa, Choong et al. (2005) for Malaysia, and Shahbaz et al. (2011) for Pakistan, but contrary to those of Abdulai and Jacquet (2002) for Cote d'Ivoire, Rangasamy (2009) for South Africa, and Afzal and Hussain (2010); Kumari and Malhotra (2015) and Hassan and Murtala (2016) for Pakistan. A potential explanation for the conflicting results is that this study considers longer sample period compared to the existing studies. Furthermore, in the presence of frequent structural changes, the pattern of the causal relationships between exports and GDP will show instability across different sub-samples and the full sample causality tests will not reflect such changes. For this reason, we proceed to test for parameter stability in the cointegrating and the causal relationships.

Table-5. Full sample Granger causality test

\begin{tabular}{|c|c|c|c|c|c|}
\hline & $\operatorname{Lag}(p)$ & \multicolumn{2}{|c|}{ 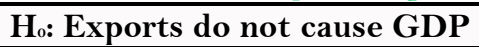 } & \multicolumn{2}{|c|}{$H_{0}:$ GDP does not cause Exports } \\
\hline Country & & Stat. & $p$-value & Stat. & p-value \\
\hline Cote d'Ivoire & 1 & 2.068 & 0.141 & 0.371 & 0.551 \\
\hline Malaysia & 2 & $6.397^{*}$ & 0.049 & 2.304 & 0.337 \\
\hline Pakistan & 4 & $10.00^{* * *}$ & 0.060 & 2.570 & 0.635 \\
\hline South Africa & 2 & 2.592 & 0.271 & $8.082^{*}$ & 0.020 \\
\hline
\end{tabular}

\subsection{Parameter Stability Test Results}

We test the temporal stability of both the long-run and short-run parameters. We test the stability of the longrun relationships using the $\mathrm{L}_{\mathrm{c}}$ statistic proposed by Hansen (1992). The stability of the short-run parameters was tested using the Sup-F, Mean-F and Exp-F statistics (Andrews, 1993; Andrews and Ploberger, 1994). The outcome of these tests is reported in Table 6. The results suggest that the long-run correlations between exports and GDP are not constant for the four countries. Therefore, we can conclude that exports and GDP do not maintain a stable long-run relationship. With respect to the short-run parameters, the results show that the null hypothesis of parameter constancy in both GDP and export equations is rejected for all countries. Overall, these results provide evidence of instability in the parameters of our models. Therefore, inferences based on the full sample are no longer reliable. On this basis we reexamine the relationship between exports and GDP using the rolling window regression technique.

Table-6. Parameter stability tests

\begin{tabular}{l|l|l|l|l|l|l|l|l}
\hline \multirow{2}{*}{ Country } & \multicolumn{9}{|l}{ GDP equation } & \multicolumn{1}{l}{ Export equation } \\
\cline { 2 - 10 } & Sup-F & Exp-F & Mean-F & $\mathbf{L}_{\mathbf{c}}$ & Sup-F & Exp-F & Mean-F & $\mathbf{L}_{\mathbf{c}}$ \\
\hline Cote d'Ivoire & $39.342^{*}$ & $17.557^{*}$ & $24.667^{*}$ & $1.182^{*}$ & $29.595^{*}$ & $12.283^{*}$ & 10.447 & 0.392 \\
& $(0.000)$ & $(0.000)$ & $(0.000)$ & $(<0.01)$ & $(0.005)$ & $(0.002)$ & $(0.178)$ & $(>0.2)$ \\
\hline Malaysia & $39.684^{*}$ & $17.017^{*}$ & $23.432^{*}$ & $0.948^{*}$ & $43.981^{*}$ & $19.661^{*}$ & $30.608^{*}$ & 0.416 \\
& $(0.000)$ & $(0.000)$ & $(0.000)$ & $(<0.01)$ & $(0.000)$ & $(0.000)$ & $(0.000)$ & $(0.177)$ \\
\hline Pakistan & $66.004^{*}$ & $30.932^{*}$ & $52.171^{*}$ & $0.768^{*}$ & $48.202^{*}$ & $22.438^{*}$ & $35.004^{*}$ & 0.349 \\
& $(0.000)$ & $(0.000)$ & $(0.000)$ & $(0.029)$ & $(0.000)$ & $(0.000)$ & $(0.002)$ & $(>0.20)$ \\
\hline South Africa & $34.708^{*}$ & $14.591^{*}$ & $20.250^{*}$ & $1.666^{*}$ & $48.786^{*}$ & $21.207^{*}$ & $21.838^{*}$ & $0.412^{* *}$ \\
& $(0.005)$ & $(0.003)$ & $(0.014)$ & $(<0.01)$ & $(0.000)$ & $(0.000)$ & $(0.007)$ & $(0.077)$ \\
\hline Note: ${ }^{*}$ and ${ }^{* *}$ denote significance at $5 \%$ and $10 \%$, respectively.
\end{tabular}

\subsection{Rolling Cointegration and Causality Tests Results}

The results of the rolling bounds test are plotted in Figure 1, with the horizontal axis showing the final observation in each of the 25-year rolling window and the vertical axis recording the maximum of normalized Fstatistics. This figure reveals evidence of significant changes in the cointegrating relationships over the sample period. For Cote d'Ivoire, exports, capital formation and GDP are cointegrated from 1965 to 1989; however these variables are not coalescing in the long-run for years 1990, 1994 and 1997-1999. For Pakistan, the three variables are cointegrated from 1967 to 2014 except for years 1998 and 2001-2002. In the cases of Malaysia and South Africa, the three variables are cointegrated over the period 1960-2014.

Cote d'lvoire

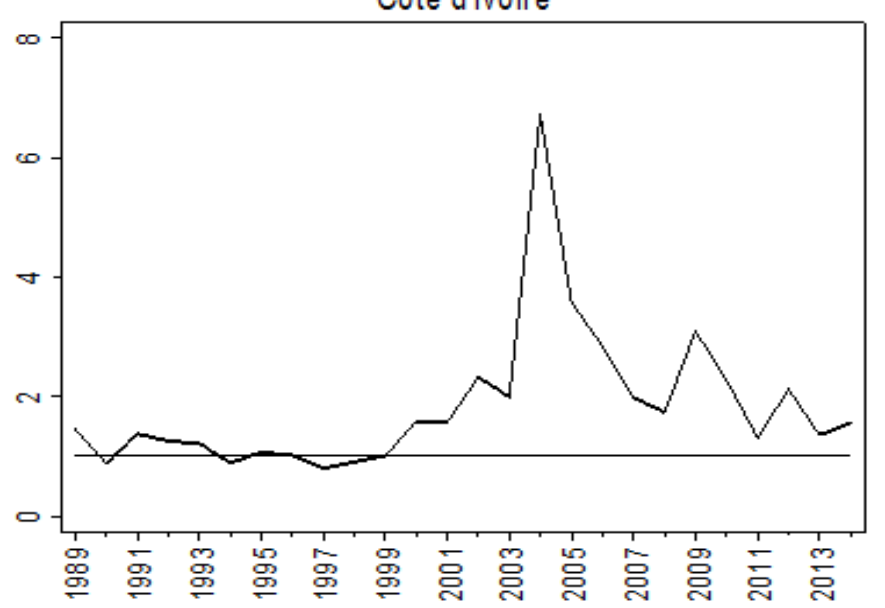

Pakistan

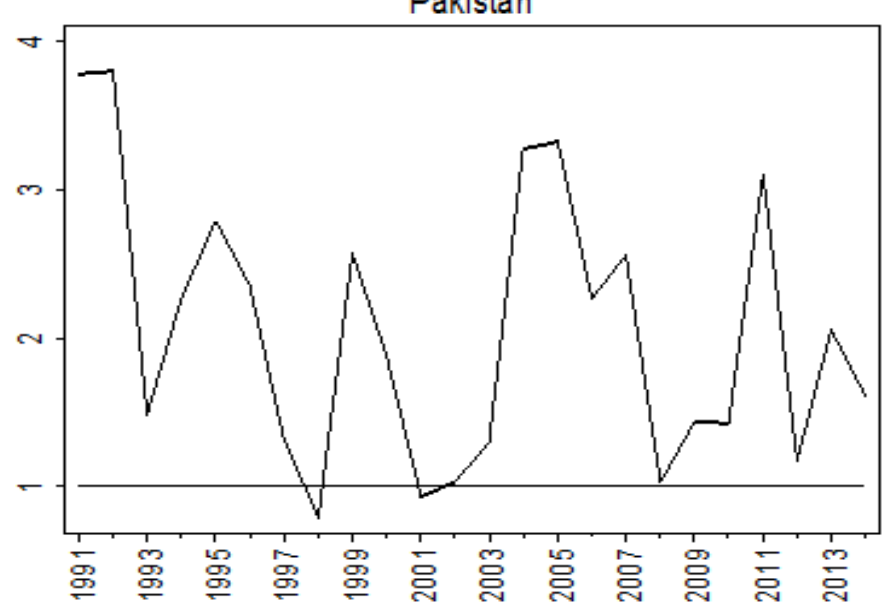


Malaysia
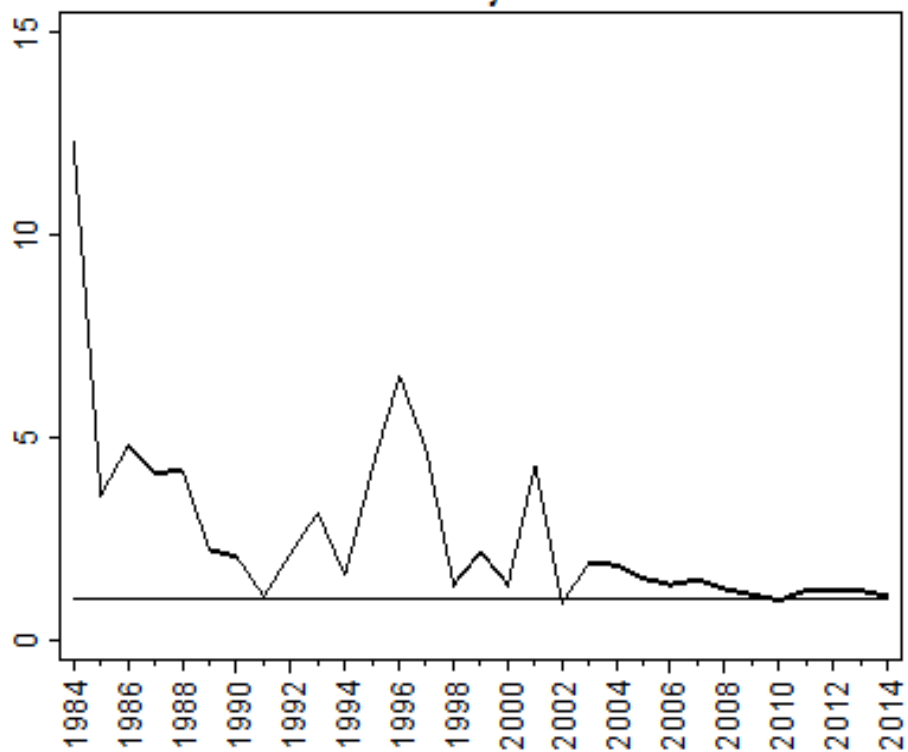

South Africa

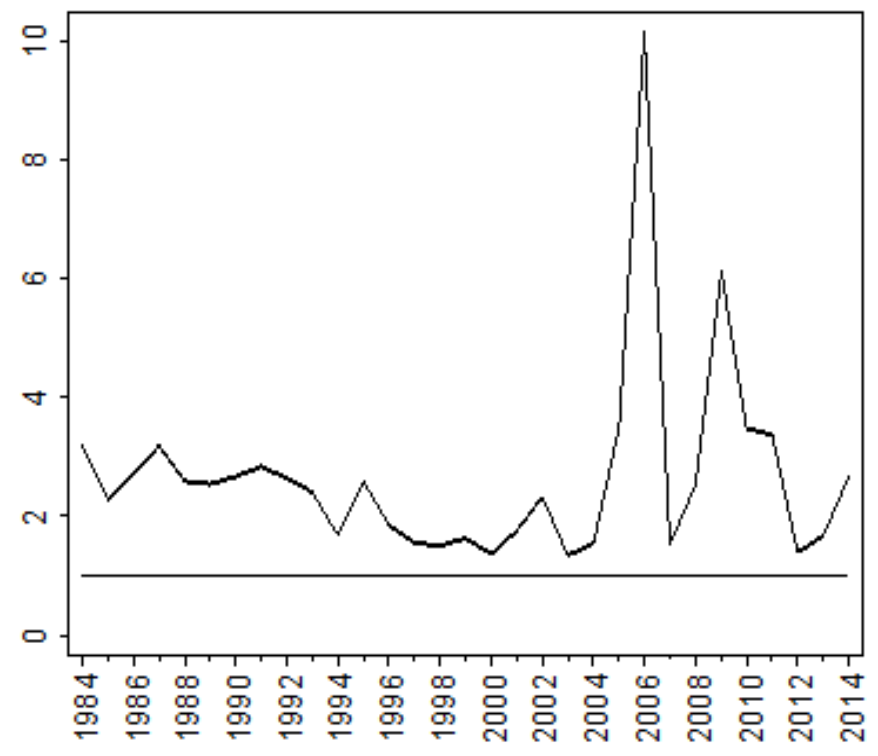

Table-7. Selected lag orders for rolling VAR models

\begin{tabular}{|c|c|c|c|c|}
\hline Year & Cote d'Ivoire & Malaysia & Pakistan & South Africa \\
\hline 1984 & & 4 & & 4 \\
\hline 1985 & & 4 & & 4 \\
\hline 1986 & & 5 & & 5 \\
\hline 1987 & & 5 & & 5 \\
\hline 1988 & & 5 & & 5 \\
\hline 1989 & 1 & 5 & & 5 \\
\hline 1990 & 1 & 5 & & 5 \\
\hline 1991 & 5 & 5 & 4 & 4 \\
\hline 1992 & 5 & 5 & 4 & 5 \\
\hline 1993 & 5 & 5 & 4 & 4 \\
\hline 1994 & 5 & 5 & 4 & 5 \\
\hline 1995 & 1 & 4 & 4 & 5 \\
\hline 1996 & 1 & 4 & 4 & 5 \\
\hline 1997 & 2 & 4 & 5 & 4 \\
\hline 1998 & 2 & 5 & 5 & 5 \\
\hline 1999 & 5 & 5 & 5 & 3 \\
\hline 2000 & 5 & 5 & 5 & 5 \\
\hline 2001 & 5 & 5 & 5 & 3 \\
\hline 2002 & 5 & 5 & 5 & 5 \\
\hline 2003 & 5 & 5 & 5 & 5 \\
\hline 2004 & 5 & 5 & 4 & 5 \\
\hline 2005 & 5 & 2 & 5 & 5 \\
\hline 2006 & 5 & 2 & 5 & 5 \\
\hline 2007 & 5 & 2 & 5 & 5 \\
\hline 2008 & 5 & 2 & 5 & 5 \\
\hline 2009 & 5 & 2 & 5 & 5 \\
\hline 2010 & 5 & 2 & 5 & 5 \\
\hline 2011 & 5 & 2 & 5 & 5 \\
\hline 2012 & 5 & 1 & 5 & 5 \\
\hline 2013 & 5 & 1 & 5 & 5 \\
\hline 2014 & 1 & 1 & 5 & 3 \\
\hline
\end{tabular}

We now examine the time-varying causal relationships between exports and GDP. In most studies using rolling regression technique, the lag length of the rolling VARs is assumed to be constant over time. Here we relax this assumption and allow the rolling VARs to have different lag lengths. Because the window size is 25 , a total of 31 lag lengths over the period 1984-2014 were selected for Malaysia and South Africa, while 26 and 24 lag lengths were selected for Cote d'Ivoire and Pakistan, respectively. The lag orders selected for each rolling VAR and each country are summarized in Table 7. The lag lengths selected for the rolling VARs are in general higher than those of the full sample VARs and show variation across windows, reflecting the time-varying nature of the full-sample VAR models. The bootstrap p-values of the rolling Wald-tests are shown in Figure 2. 
Cote d'Ivoire
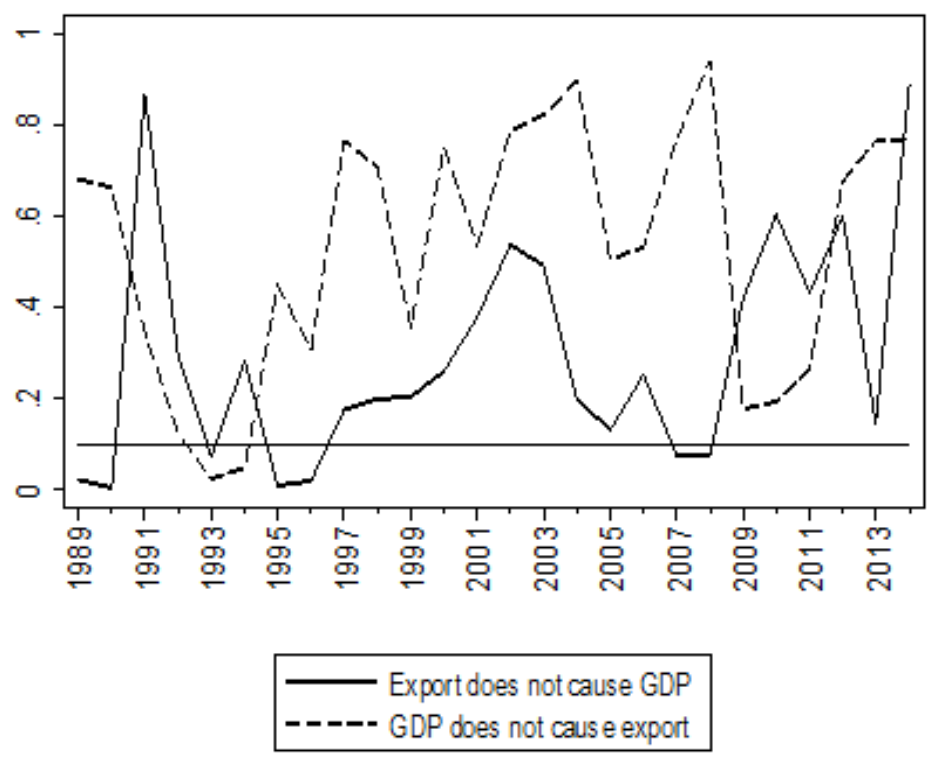

Pakistan

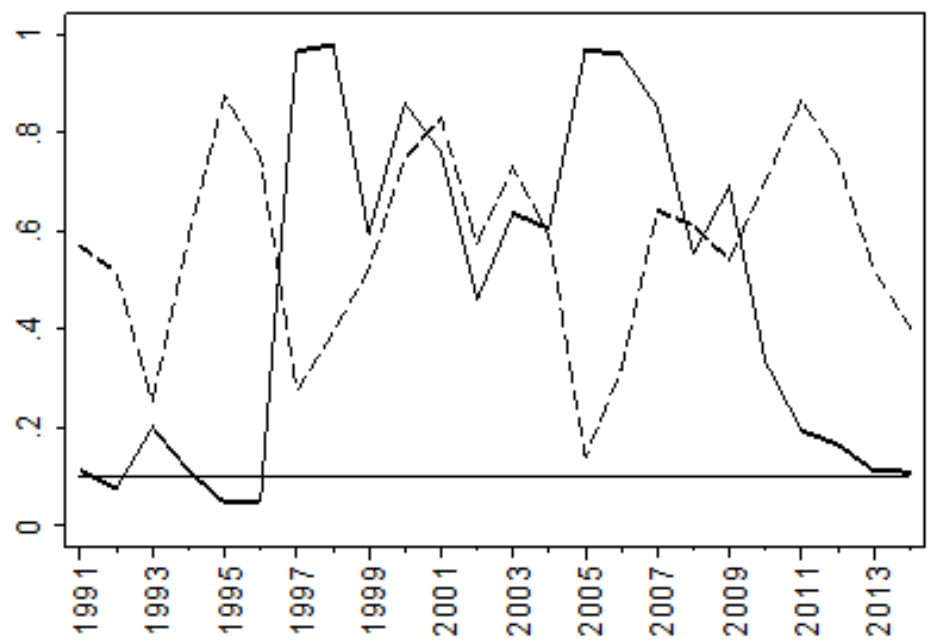

Malaysia
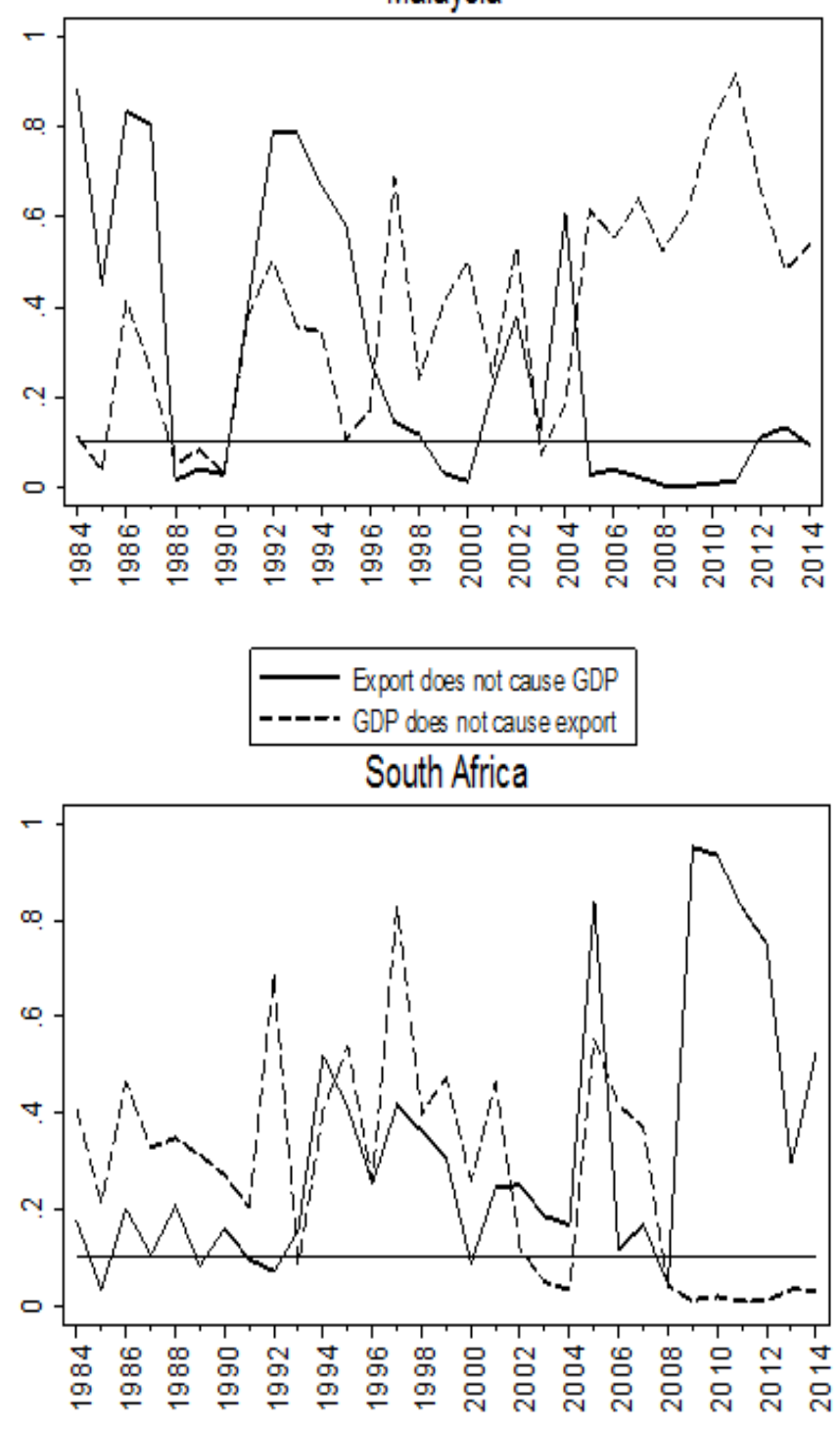

Export does not cause GDP

GDP does not cause export

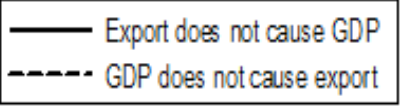

Figure-2. Rolling window bootstrap p-values of Granger non-causality Wald-tests

Figure 2 shows that the causal nexus between exports and GDP is unstable over time. For Cote d'Ivoire, exports cause GDP for the 1989-1990, 1996 and 2007-2008 sub-periods, while GDP causes exports in 1994 and the two variables mutually cause each other in 1993. The result for these periods may be attributed to the economic crisis in 1990, the devaluation of the CFA Franc currency in 1994 and the political crisis in September 1999, which led to political tension up to 2008. The finding of causal relationship between exports and GDP contradicts with the full sample test results.

Results for Malaysia indicate that GDP has predictive power for exports for the years 1985 and 2003, while exports have predictive content for GDP for the sub periods 1999-2000, 2005-2011 and 2014, and a two-way causal relationship occurs from 1988 to 1990. These unstable causal links between exports and economic growth in Malaysia can be due to some important events such as the World economic recession in the mid-1980s; the realignment of currencies after the Plaza Agreement in 1985; the Asian financial crisis in 1997/98; the implementation of a pegged exchange rate and the capital control from 1998 to 2000; the severe acute respiratory syndrome and avian flu in 2003; and the global financial crisis in 2008. For Pakistan, exports cause real GDP in 1992 and the sub-period 1995-1996. The results for South Africa show evidence of causality running from exports to GDP for the years 1985 and 1989 and for the period 1991-1992. There is also a causality running from GDP to exports in 1993, and for the sub-periods 2003-2004 and 2009-2014. A two-way causal relationship occurs in 2008. These results highlight the importance of accounting for structural breaks and nonlinearities when examining the relationship between exports and economic growth given the contrast between the full sample and the rolling window tests results. Our findings of instability of the causal relationship between exports and economic growth may partially explain the conflicting causality results in the existing empirical literature.

\section{Conclusion}

The study reexamines the relationship between exports and economic growth for Cote d'Ivoire, Malaysia, Pakistan and South Africa, with two objectives. First, it tests whether there is a causal link between exports and economic growth. Second, the study tests whether the causal relationship between the two variables is stable over time or time-varying. As opposed to previous studies the study uses the rolling window regression-based cointegration and causality tests. We first applied the full sample bounds test to cointegration which showed that exports, investment in physical capital and GDP share long-run relationships in the four countries. Also, the full sample Granger causality tests support the export-led growth hypothesis for Malaysia and Pakistan, and the growth-led exports hypothesis for South Africa. There is no significant causal link between exports and real GDP 
for Cote d'Ivoire. However, parameter stability tests make clear that these results are not uniform for different sample periods and vary due to structural changes, indicating that the full sample results are not reliable. Therefore, the rolling window cointegration and causality tests were applied with a window size of 25 years. The results showed that the long-run and also the causal relationships between exports and GDP in each of the four countries are not stable over time. For most time periods we do not find any causal relationship between exports and GDP. There are, however, sub-periods during which unidirectional or bidirectional causal links were found. To sum up, the results of this study show that there is no stable causal relationship between exports and economic growth. The causal nexus between the two variables is time-varying. This suggests that traditional linear models that assume a constant and stable relation over time may not be appropriate to analyze the relationship between exports and economic growth. As such, researchers should use methods that account for structural changes and nonlinearities in the dynamic causal relationship between exports and economic growth. The time-varying nature of the exports and economic growth nexus may explain partly the conflicting causality evidence obtained by previous studies. It is evident that different directions of causality over time need different policy responses and therefore export-promoting strategies are not always and everywhere effective tools to stimulate economic growth. An interesting avenue for future research is the investigation of the determinants of the time-varying relationship between exports and economic growth in the four countries under study.

\section{References}

Abdulai, A. and P. Jacquet, 2002. Exports and economic growth: Cointegration and causality evidence for Cote d'Ivoire. African Development Review, 14(1): 1-17. Available at: https://doi.org/10.1111/1467-8268.00043.

Afzal, M. and I. Hussain, 2010. Export-led growth hypothesis: Evidence from Pakistan. Journal of Quantitative Economics, 8(1): 130-147.

Ahmad, J. and A.C. Kwan, 1991. Causality between exports and economic growth: Empirical evidence from Africa. Economics Letters, 37(3): $243-248$.

Al-Yousif, Y.K., 1999. On the role exports in the economic growth of Malaysia: A multivariate analysis. International Economic Journal, 13(3): 67-75. Available at: https://doi.org/10.1080/10168739900000006.

Alimi, S., 2012. Is the export-led growth hypothesis valid for Nigeria. Research Journal of Economics and Business Studies, 12(2): 8-14.

Alimi, S.R. and B.O. Muse, 2013. Export-led growth or growth-driven exports? Evidence from Nigeria. British Journal of Economics, Management and Trade, 3(2): 89-100. Available at: https://doi.org/10.9734/bjemt/2013/2386.

Andrews, D.W., 1993. Tests for parameter instability and structural change with unknown change point. Econometrica: Journal of the Econometric Society, 61(4): 821-856. Available at: https://doi.org/10.2307/2951764.

Andrews, D.W. and W. Ploberger, 1994. Optimal tests when a nuisance parameter is present only under the alternative. Econometrica: Journal of the Econometric Society: 1383-1414. Available at: https://doi.org/10.2307/2951753.

Arodoye, N.L. and M.A. Iyoha, 2014. Foreign trade-economic growth nexus: Evidence from Nigeria. CBN Journal of Applied Statistics, 5(1): 121-141.

Baharumshah, A.Z. and S. Rashid, 1999. Exports, imports and economic growth in Malaysia: Empirical evidence based on multivariate time series. Asian Economic Journal, 13(4): 389-406. Available at: https://doi.org/10.1111/1467-8381.00092.

Bahmani-Oskooee, M., 1993. Export growth and economic growth: An application of cointegration and error-correction modeling. The Journal of Developing Areas, 27(4): 535-542.

Bahmani-Oskooee, M. and C. Economidou, 2009. Export led growth vs. growth led exports: LDCs Experience. The Journal of Developing Areas, 42(2): 179-209. Available at: https://doi.org/10.1353/jda.0.0030.

Chandra, R., 2003. Reinvestigating export-led growth in India using a multivariate cointegration framework. The Journal of Developing Areas, 37(1): 73-86. Available at: https://doi.org/10.1353/jda.2004.0005.

Chandra, R. and J. Love, 2005. Testing export-led growth in Bangladesh in a multivarate VAR framework. Journal of Asian Economics, 15(6): 1155-1168. Available at: https://doi.org/10.1016/j.asieco.2004.11.009.

Cheung, Y.-W. and K.S. Lai, 1993. Finite sample sizes of Johansen's likelihood ratio tests for cointegration. Oxford Bulletin of Economics and Statistics, 55(3): 313-328. Available at: https://doi.org/10.1111/j.1468-0084.1993.mp55003003.x.

Choong, C.K., Z. Yusop and V.K.S. Liew, 2005. Export-led growth hypothesis in Malaysia: An investigation using bounds test. Sunway Academic Journal, 2: 13-22.

Dhawan, U. and B. Biswal, 1999. Re-examining export-led growth hypothesis: A multivariate cointegration analysis for India. Applied Economics, $31(4): 525-530$.

Dodaro, S., 1993. Exports and growth: A reconsideration of causality. The Journal of Developing Areas, 27(2): 227-244.

Dolado, J.J. and H. Lütkepohl, 1996. Making wald tests work for cointegrated VAR systems. Econometric Reviews, 15(4): 369-386. Available at: https://doi.org/10.1080/07474939608800362.

Ekanayake, E., 1999. Exports and economic growth in Asian developing countries: Cointegration and error-correction models. Journal of Economic Development, 24(2): 43-56.

Furuoka, F., 2007. Do exports act as "engine" of growth? Evidence from Malaysia. Economics Bulletin, 6(37): 1-14.

Hamdi, H., 2013. Testing export-led growth in Tunisia and Morocco: New evidence using the Toda and Yamamoto procedure. Economics Bulletin, 33(1): 677-686.

Hansen, B.E., 1992. Tests for parameter instability in regressions with I (1) processes. Journal of Business and Economic Sta tistics, 10(3): 32 1-335. Available at: https://doi.org/10.1080/07350015.1992.10509908.

Hassan, S. and M. Murtala, 2016. Market size and export-led growth hypotheses: New evidence from Malaysia. International Journal of Economics and Financial Issues, 6(3): 971-977.

Hatemi-j, A., 2002. Export performance and economic growth nexus in Japan: A bootstrap approach. Japan and the World Economy, 14(1): 25-33. Available at: https://doi.org/10.1016/s0922-1425(01)00071-8.

Inder, B., 1993. Estimating long-run relationships in economics: A comparison of different approaches. Journal of Econometrics, 57(1-3): 5368. Available at: https://doi.org/10.1016/0304-4076(93)90058-d.

Islam, M.N., 1998. Export expansion and economic growth: Testing for cointegration and causality. Applied Economics, 30(3): 415-425. Available at: https://doi.org/10.1080/000368498325930.

Jarra, S.T., 2013. Exports, domestic demand and economic growth in Ethiopia: Granger causality analysis. Journal of Economics and International Finance, 5(9): 357-372. Available at: https://doi.org/10.5897/jeif2013.0537.

Jordaan, A.C. and J.H. Eita, 2007. Export and economic growth in Namibia: A Granger causality analysis. South African Journal of Economics, 75(3): 540-547. Available at: https://doi.org/10.1111/j.1813-6982.2007.00132.x.

Khalafalla, K.Y. and A.J. Webb, 2001. Export-led growth and structural change: Evidence from Malaysia. Applied Economics, 33(13): 17031715 .

Khan, A.H. and N. Saqib, 1993. Exports and economic growth: The Pakistan experience. International Economic Journal, 7(3): 53-63. Available at: https://doi.org/10.1080/10168739300080020.

Kumari, D. and N. Malhotra, 2014. Export-led growth in India: Cointegration and causality analysis. Journal of Economic and Development Studies, 2(2): 297-310.

Kumari, D. and N. Malhotra, 2015. Export and economic growth in select South Asian countries: Causality analysis based on Granger Test \& VECM. Arthshastra: Indian Journal of Economics \& Research, 4(4): 21-36. Available at: https://doi.org/10.17010/aijer/2015/v4i4/77668.

Lam, T.D., 2016. An empirical analysis of the ASEAN-4's causality between exports and output growth. International Journal of Economics and Financial Issues, 6(2): 497-502. 
Love, J. and R. Chandra, 2004. Testing export led growth in India, Pakistan and Sri Lanka using a multivariate framework. The Manchester School, 72(4): 483-496. Available at: https://doi.org/10.1111/j.1467-9957.2004.00404.x.

Lütkepohl, H., 1982. Non-causality due to omitted variables. Journal of Econometrics, 19(2-3): 367-378. Available at: https://doi.org/10.1016/0304-4076(82)90011-2.

Mahadevan, R., 2007. New evidence on the export-led growth nexus: A case study of Malaysia. The World Economy, 30(7): 1069-1083. Available at: https://doi.org/10.1111/j.1467-9701.2007.01030.x.

Mamun, K.A. and H.K. Nath, 2005. Export-led growth in Bangladesh: A time series analysis. Applied Economics Letters, 12(6): 361-364. Available at: https://doi.org/10.1080/13504850500068194.

Parida, C.P. and P. Sahoo, 2007. Export-led growth in South Asia: A panel cointegration analysis. International Economic Journal, $21(2)$ : 155-175. Available at: https://doi.org/10.1080/10168730701345414.

Pesaran, M.H., Y. Shin and R.J. Smith, 2001. Bounds testing approaches to the analysis of level relationships. Journal of Applied Econometrics, 16(3): 289-326. Available at: https://doi.org/10.1002/jae.616.

Phillips, P.C. and P. Perron, 1988. Biometrika, 75(2): 335-346. Available at: https://doi.org/10.2307/2336182.

Rangasamy, L., 2009. Exports and economic growth: The case of South Africa. Journal of International Development: The Journal of the Development Studies Association, $21(5)$ : 603-617. Available at: https://doi.org/10.1002/jid.1501.

Reppas, P.A. and D.K. Christopoulos, 2005. The export-output growth nexus: Evidence from African and Asian countries. Journal of Policy Modeling, 27(8): 929-940. Available at: https://doi.org/10.1016/j.jpolmod.2005.06.007.

Saleem, A. and M.H. Sial, 2015. Exports-growth nexus in Pakistan: Cointegration and causality analysis. Pakistan Economic and Social Review, 53(1): 17-46.

Shahbaz, M., P. Azim and K. Ahmad, 2011. Export-led growth hypothesis in Pakistan: Further evidence. Asian Economic and Financial Review, 1(3): 182-197.

Shirazi, N.S. and T.A.A. Manap, 2005. Export led growth hypothesis: Further econometric evidence from South Asia. The Developing Economies, 43(4): 472-488. Available at: https://doi.org/10.1111/j.1746-1049.2005.tb00955.x.

Srivastava, D.K. and G. Kapoor, 2007. Test of export-led growth and growth-led export hypotheses in Indian context: An econometric analysis for the period of 1951-2004. Asia Pacific Management Review, 12(2): 113-115.

Tang, C.F., 2013. A revisitation of the export-led growth hypothesis in Malaysia using the leveraged bootstrap simulation and rolling causality techniques. Journal of Applied Statistics, 40(11): 2332-2340. Available at: https://doi.org/10.1080/02664763.2013.810195

Tang, C.F., Y.W. Lai and I. Ozturk, 2015. How stable is the export-led growth hypothesis? Evidence from Asia's four little dragons. Economic Modelling, 44: 229-235. Available at: https://doi.org/10.1016/j.econmod.2014.09.022.

Tang, T.C., 2006. New evidence on export expansion, economic growth and causality in China. Applied Economics Letters, 13(12): 801-803. Available at: https://doi.org/10.1080/13504850500425303.

Toda, H.Y. and T. Yamamoto, 1995. Statistical inference in vector autoregressions with possibly integrated processes. Journal of Econometrics, 66(1-2): 225-250. Available at: https://doi.org/10.1016/0304-4076(94)01616-8.

Tsen, W.H., 2010. Exports, domestic demand, and economic growth in China: Granger causality analysis. Review of Development Economics, 14(3): 625-639. Available at: https://doi.org/10.1111/j.1467-9361.2010.00578.x.

Ukpolo, V., 1998. . Exports and economic growth in South Africa: Evidence from cointegration and Granger-causality tests. The African Economic and Business Review, 1(1): 1-6.

Yang, M.-H. and C.-S. Wu, 2015. Revisit export and GDP nexus in China and Taiwan: A rolling window Granger causality test. Theoretical and Applied Economics, 22(3): 75-92. 